\title{
The Influence of Corporate Governance Systems on a Company's Market Value
}

\author{
Ionica Oncioiu 1,*(D), Anca-Gabriela Petrescu ${ }^{2}$, Florentina-Raluca Bîlcan ${ }^{2}$, Marius Petrescu ${ }^{2}$, \\ Melinda Timea Fülöp ${ }^{3}$ and Dan Ioan Topor ${ }^{4}$ \\ 1 Faculty of Finance-Banking, Accountancy and Business Administration, Titu Maiorescu University, \\ 040051 Bucharest, Romania \\ 2 Faculty of Economic Sciences, Valahia University, 130024 Targoviste, Romania; \\ anki.p_2007@yahoo.com (A.-G.P.); bilcan.florentina.raluca@gmail.com (F.-R.B.); \\ petrescu.marius_m@yahoo.com (M.P.) \\ 3 Faculty of Economics and Business Administration, Babeş-Bolyai University, 400591 Cluj-Napoca, Romania; \\ melinda.timea.fulop.edu@gmail.com \\ 4 Faculty of Economic Sciences, 1 Decembrie 1918 University, 510009 Alba-Iulia, Romania; \\ topor.dan.ioan@gmail.com \\ * Correspondence: nelly_oncioiu@yahoo.com
}

Received: 20 March 2020; Accepted: 7 April 2020; Published: 14 April 2020

check for updates

\begin{abstract}
Recent world events have refocused interest on the link between the existence of corporate governance and an entity's effectiveness. The aim of this study was to identify the influence of the corporate governance system of an entity in order to measure its effects on market value. To achieve quality corporate governance and to increase an audit committee's degree of effectiveness, one must take into consideration four core elements: members' qualifications, authority, the resources necessary to develop the activity, and attention during the development of the activity. Our research methodology included a combination of qualitative analyses on theoretical aspects and a quantitative approach based on multiple regression and the estimation method. The main results showed that there is a solid link between strong corporate governance systems and effective audit committees, although we cannot state that the inclusion of an audit committee represents the key to success for a business. When studying the connection between audit committees and an entity's market value, we found that this connection can lead to alleviating the problem of allocating power (principal-agent theory). We also found that the contribution of audit committees in corporate governance is to assess both the quality of financial reports and their approval and that creating an audit committee can have beneficial effects that can eventually lead to the consolidation of a company's corporate governance.
\end{abstract}

Keywords: corporate governance; audit committee; market value; financial reports; sustainability

\section{Introduction}

Contemporary discussions about business emphasize the themes of responsible, sustainable business, such as corporate social responsibility, corporate governance, and sustainable development [1-3]. In this context, values, especially "sustainable business values," are popular themes in the literature, which has often focused on the economy-governance-environment relationship [4-8]. However, several variables affect the sustainable business value of firms, and corporate governance systems and sustainability are synergistic constructs [9-11]. This approach has led to new, sustainable business opportunities, as it creates new markets, strengthens competitive positioning, and improves profitability [12,13].

On the other hand, corporate sustainability and responsibility exist when a company adds a social dimension to its market value proposition $[14,15]$. This happens when organizations make 
laudable environmental and social impacts that are integral to their overall corporate governance system. The rationale behind corporate responsibility lies in creating value and finding win-win outcomes for both business and society $[15,16]$. Sustainable governance and responsibility is about embedding sustainability by searching for and connecting with all interested parties [17-19].

In this context, the need to determine the impact of different types of corporate governance systems on a company's market value has been a focal point for both national and international standardization institutes, as well as for researchers and practitioners [18-27]. Thus, as an important part of the corporate governance system, the effect of audit committees on the various characteristics of information quality, and thus company performance, has become the main attraction of researchers, specialists, and investors alike.

Another concern is identifying reliable solutions to ensure the implementation of proactive and prospective risk management that makes a mark on the utility of the information being presented and communicated to the targeted users, especially through accounting reporting $[10,28]$.

In the efforts of national and international organizations to publish standards and instructions on restoring the credibility of financial information and financial statements provided by companies, one important aspect is that of the role of an audit in enhancing the functioning and independence of external auditors (as independent parties issuing endorsements of objectively and correctly stated data) [29]. An active audit committee depends on a number of factors: committee dimension, experience, expertise, degree of independence, and the frequency of meetings [30-33].

The Sarbanes-Oxley Act (2002) introduced a series of reforms, such as the right to declare, the submission of financial reports by the corporate governance of foreign companies, and the monitoring of account auditors [33,34]. Moreover, some codes of corporate governance contain recommendations regarding what kind of accounting reporting is recommended; what standards the reports should comply with; and the necessity of internal controls, rigorous risk management, internal auditing, and an audit committee [33-35].

Empirical studies have presented consistent results about the role of audit committees, including tools that can be used to supervise and directly assess management performance [36-39]. It is also worth noting that governance systems and practices have to be adapted to the specifics of each entity, as well as to the environment in which they function; in this way, the implementation and functioning of some structures of corporate governance (especially those that determine the reporting process, in which the integrity and transparency of accounting approaches is essential) can be assured [36,37].

According to the Eighth E.U. Company Law Directive, the tasks and responsibilities of an audit committee include increasing the quality of corporate governance and financial reporting. The purpose of this study was to analyze the manner in which Romanian corporate governance systems and audit committees influence an entity's market value and financial performance. The main results showed that investors are willing to offer a higher value for shares held by an entity with corporate governance, as these companies provide greater reliability than do those that do not apply these codes of corporate governance. The intention of the authors was to research and analyze the influence of an audit committee on the market value of a company.

This study also makes contributions to the existing literature. First, this research strongly suggests that striving to ensure the accuracy and credibility of financial information is a vital task, and this task requires first knowing the incremental value of an audit committee. Second, prior studies seem to have evaluated reporting and assurance processes in terms of the market value of a company. By drawing attention to the importance of the unobserved components of governance mechanisms, this study tries to break this habit in order to understand the specific role of audit committees in a company's value.

This paper is structured in the following way: Section 2 analyzes a series of previous studies on the influence of corporate governance systems on a company's market value. Section 3 presents the research methodology. In the next section, Section 4, the empirical results and discussion draw attention to the link between strong corporate governance systems and effective audit committees. The main conclusions of this research are provided in Section 5. 


\section{Literature Review and Hypothesis Development}

The stakeholder perspective in approaching economic performance may have several approaches, diversified according to the nature of their interest in the entity [40-42]. The interests of the managers can often be very different from the interests of the shareholder in the issue of performance. The principles that govern any entity that has a leadership based on corporate governance implicitly converge in performance reporting, under all significant global issues considered, by considering it as an essential element in the entity's sustainable development.

Prior research presents that large sets of corporate governance such as boards of directors (audit committees as well), managers, foreign investors, institutional investors, external auditors, and others affect accounting quality, thereby influencing a company's market value and operational performance $[36,39,43]$. As a consequence, the audit committee within an entity represents a core element of corporate governance $[37,39,40]$. In practice, the audit committee is an intermediary between the board of directors and the board of commissioners, and it is responsible for the overall implementation of the internal audit with the aim to supervise the performance of the company [43].

Furthermore, the effort to define the role of audit committee seems to overwhelmingly encourage audit quality research bodies to focus on a financial reporting quality perspective [38,43]. Handling financial results in the reporting of the financial statements provides benefits only in the short term. Manipulating accounts can affect the stock price and, consequently, the capital market, increasing the risk of losing investors. That is why the literature measures audit quality by financial reporting quality indicators such as accounting conservatism, value relevance of earnings over a long period, and even twenty-eight audit quality indicators issued by the Public Company Accounting Oversight Board (PCAOB) [44,45].

The advantages of implementing an audit committee department within an entity are [37,41]: (1) greater confidence of the public concerning annual financial statements; (2) confirmation that the entity is subjected to the corporate governance rules and that it applies the best practices of corporate governance; (3) supervision of financial statements' preparation in accordance with the laws, norms, and regulations in force and with the best practices of corporate governance; (4) improvement of the internal and external audit activities; (5) assessment of the activity undertaken by the financial and accounting department; (6) improvement of internal control; (7) an intermediate between internal audit, external audit, and management; (8) support for the quality and independence of the internal and external audit.

In recent years, the role of audit committee has become of considerable interest as a key mechanism of corporate governance [46-48]. Corporate governance committees and regulatory authorities around the world have approached the need for an effective audit committee, and moreover, they require that listed companies create an audit committee (in the European Union). After admitting that the existence of an audit committee does not guarantee that it will be effective, the focus shifted to the composition and activities of the audit committees. The recommendations focused on the independence and expertise of committee members and also on the frequency of audit committee meetings [34]. The research performed in this field suggests that there is a considerable divergence within the recommended structure and the role of audit committees [31,44].

The role of the audit committee is to supervise and control the audit process and to resolve any dispute that may arise between auditors and management [42]. The audit committee has a very important role in protecting the interests of the shareholders and the reliability of the communicated information [32,39], appointment of external auditors, assessing the company's financial statements at meetings between external auditors and managers, and communication between external and internal auditors during the process of internal control or audit [45-48].

Existent research on audit committee monitoring effectiveness and competencies could be recognized as relatively developed, whereas corporative social responsibility reporting is a research area that is yet to be developed compared to the former. However, most authors believe that the existence of audit committees is necessary, but they do not contribute to improving the quality of 
financial reporting $[36,38,48]$. In this regard, the audit/financial reporting quality and corporate social responsibility reporting have both similarities and key differences between them: (1) reducing information asymmetry between counterparties in the markets and (2) showing how the reporting companies are functioning economically and to what degree the financial or nonfinancial information is credible. In addition, the complex activity of the audit committee gives to a commercial entity not only a reasonable assurance for the shareholders but also additional credibility and great visibility regarding the stakeholders in order to attract new investors.

The correlation between the frequency of meetings of members of the audit committee and the financial performance of a company has been studied by specialists who have shown that the low frequency of meetings of audit committee members has led to fraud [47,48], the increase of accounting and financial reporting problems [30,49], and the increase of beneficial effects of reporting on the value of the company resulting from the fact that the benefits exceed the costs of a company $[29,32]$.

Specialist studies have shown a correlation between the independence of the audit committee, the level of supervision, and the level of fraud in the financial statements such as: the independence of audit committee members influences the reliability of financial statements [39,50]; committees composed of a certain percentage of external directors are more independent than other committees $[33,45,51,52]$; a positive influence of the audit committee is exerted on the quality of earnings [46] or the quality of the financial statements [53]; the effectiveness of the audit committee influences the timely presentation of financial statements [52-56].

Another correlation identified by the specialists is related to the degree of responsibility, the expertise of the members of the audit committee, and the financial performance. In fulfilling its supervisory, internal control, and financial reporting responsibilities, the audit committee should have the necessary expertise based on accounting and financial forecasting [55-57], accounting, control, and auditing [58] to ensure the superior quality of financial reporting [59]. Tenure, the regularity of the consultations, and social ties can also have an impact of great significance.

The expertise of audit committee members can be made up of financial expertise, accounting, university professors' expertise, employee expertise, and experience in law [60] or financial expertise, government expertise, and firm expertise [61,62]. The correlation between the size of the audit committee and the financial performance of a company has been studied by specialists whose results have highlighted the importance of increasing the number of members of the audit committee to ensure effective control of accounting and financial processes [61-64]. This intrinsic relationship is supported by resource dependence theory [65], ensuring transparency of information to shareholders and creditors has a positive impact on the financial performance of the company $[66,67]$.

The influence of the audit committee and the remuneration of its members based on the performance of the company revealed the following: (a) the size of the audit committee does not significantly affect the performance of the company, whether it is inspected through return on assets (ROA) or net profit margin (NPM); (b) the remuneration of the members of the audit committee does not have a significant effect on the performance of the company, whether it is inspected through ROA or NPM; (c) this contributes to the continued existence of the company; and (d) companies are expected to be able to assess the performance of their audit committees and their remuneration and maximize their performance prejudices [37]. Indeed, there is potential for further development in this promising area of sustainable governance.

Based on the discussion mentioned above, the following hypotheses are proposed:

Hypothesis (H 1): The Audit Committee Index determines the growth of an entity's market value.

Hypothesis (H 2): The average increase of turnover determines the growth of an entity's market value.

Hypothesis (H 3): The size of an entity influences the growth of its market value.

Hypothesis (H 4): The entity's profitability indicator determines the growth of its market value. 


\section{Research Method}

\subsection{Sample Data}

The analyzed data were collected from the annual reports publicly posted in the first two categories of the Frankfurt Stock Exchange. In order to obtain the necessary data for our study, we analyzed the annual reports of the 60 entities from the two categories for the years 2009, 2010, and 2011. We proposed to study these three years subsequent to the financial crisis of 2008, as we identified them as being of great significance due to the number of changes that took place in the companies' behavior. Behavioral finance is a relatively new school of thought that deals with the influence of psychology on the behavior of financial practitioners and its subsequent impact on stock markets [68,69]. It can be seen, historically, that ignoring the behavior of the decision-making process can prove to be quite expensive in the financial markets as it can result in stock market anomalies.

For this reason, awareness of behavioral biases (like representativeness, overreaction, risk aversion, herd mentality) is indispensable, furthermore identifying that the behavioral pattern both of companies and of investors in these three years is really important to identify the factors that influenced an effective or a less effective audit committee. The standardization institutions reacted to the financial crisis of 2008, but they did not have an important impact in these three years following the crisis, mostly due to the lack of time to regulate in this regard [70]. After 2011, more regulation was in order, and the companies' behavior changed accordingly [71].

After selecting the data from the 60 annual reports, we chose 53 representative entities for our study. For the 53 entities from the total of 60 , we found the necessary data for our study, therefore, the remaining 17 entities were excluded for lack of necessary data.

The analysis method is that of multiple regression, and the estimation method is the ordinary type (Ordinary Least-Squares-OLS). In order to process the data obtained from our analysis, we used SPSS, version 16, which allowed us to apply techniques of descriptive statistics and regression calculation models. Firstly, we analyzed the Audit Committee Index (ACI) using the data collected from the annual reports. Furthermore, we completed the database with the variables we needed for the regression model.

\subsection{The Development of the Research Model and the Formulation of Hypotheses}

According to the studies in the specialized literature [72-74], as a dependent variable we chose Tobin's Q coefficient. Tobin's Q compares an entity's market value (for the current year) with the value representing the replacement cost of this entity. The calculation formula for Tobin's Q indicator is

$$
\text { Tobin's Q = Market value/Value of replacement cost, }
$$

Approximate Tobin's $\mathrm{Q}=$ (Market value of equity + Book value of debts)/Total assets.

In order to measure the effectiveness degree of audit committees, in this case we decided to choose an independent variable, which consists of the following elements: the degree of independence, the existence of financial experts, the number of members, and the number of meetings. Most corporate governance codes have specifications concerning the independence, the existence of financial experts, the number of members, and the number of meetings of an audit committee.

In order to use these data, we defined the variable Audit Committee Index (ACI). ACI represents the index of the audit committee and consists of the following elements [39,44,75]: (1) degree of independence; (2) existence of a financial expert; (3) number of members; and (4) number of meetings.

As we have already mentioned, ACI is the independent variable with which we assessed the following: Is the audit committee entirely formed of independent members? Does the audit committee have at least one financial expert member? Does the audit committee consist of at least three members? Does the audit committee meet at least four times per year? 
If the criterion was met, we granted it 1 point; if the criterion was not met, we granted it 0 points. If there was no information concerning one of the criteria, we did not grant any points. In order to achieve the $\mathrm{ACI}$, we proceeded to add the points for each entity. The maximum score that an entity could achieve was 4 , and the minimum was 0 in the case of there not being any information concerning the four criteria. In order to facilitate our calculations, as other researchers such as Black et al. [76] and Baker and Wurgler [77] have already done, we created a co-scoring of the result with values between 0 and 100 .

For there to be a better and more relevant control of the entities for which we found different values regarding the Audit Committee Index, we proceeded to select certain control variables as they are also presented in the specialized literature by Beiner et al. (2006) [78]. As control variables we chose LnAssets and Growth. As Beiner et al. (2006) [78] argue, an entity's market value depends on the future potential investments. Tobin's $Q$ coefficient increases in relation to the entity's potential growth measured by using the Growth variable. The calculation formula for Growth is

$$
\text { Growth }=\text { Average increase of turnover over the last three years. }
$$

Between Tobin's $Q$ and LnAssets variables, a negative relation is expected as large entities have a lower tendency to expand. LnAssets represents the entity's size, calculated as follows:

$$
\text { LnAssets }=\ln \text { (total assets). }
$$

In order not to outsource the entity's performance, we also took into consideration the variable Return on Assets (ROA). In other studies, it was noticed that ROA has a positive influence on the entity's assessment [74,77]. It is one of the main profitability indicators of an entity, and it measures the efficiency of using assets in terms of obtained profit [78-80]. The applied calculation formula is

$$
\text { ROA }=\text { Net profit/Total assets. }
$$

In order to have an accurate record of the data collecting process, we created an overview that is

\begin{tabular}{|c|c|c|c|}
\hline Variables & Definition & Calculation Formula & Source of Data \\
\hline \multicolumn{4}{|c|}{ Dependent variable } \\
\hline Tobin's Q & $\begin{array}{l}\text { Tobin's Q compares an entity's market value } \\
\text { with the value representing the replacement } \\
\text { cost of this entity }\end{array}$ & $\begin{array}{c}\text { Tobin's } \mathrm{Q}=\text { Market } \\
\text { value/value of replacement } \\
\text { cost }\end{array}$ & Annual report \\
\hline $\mathrm{ACI}$ & $\begin{array}{l}\text { Independent var } \\
\text { Audit Committee Index (ACI) represents the } \\
\text { index of the audit committee and consists of } \\
\text { the following elements: the degree of } \\
\text { independence, the existence of financial } \\
\text { experts, the number of members, and the } \\
\text { number of meetings }\end{array}$ & Values between 0 and 100 & $\begin{array}{l}\text { The entity's } \\
\text { annual report }\end{array}$ \\
\hline \multicolumn{4}{|c|}{ Control variables } \\
\hline Growth & Average increase of turnover & $\begin{array}{c}\text { Growth = average increase } \\
\text { of turnover over the last } \\
\text { three years }\end{array}$ & Annual report \\
\hline LnAssets & $\begin{array}{l}\text { Represents the entity's size calculated using the } \\
\text { natural logarithm of the total balance sheet }\end{array}$ & LnAssets = $\ln$ (total assets) & Annual report \\
\hline ROA & $\begin{array}{l}\text { One of the main profitability indicators of an } \\
\text { entity, and it measures the efficiency of using } \\
\text { assets in terms of obtained profit. }\end{array}$ & $\begin{aligned} \text { ROA }= & \text { net profit } / \text { total } \\
& \text { assets }\end{aligned}$ & Annual report \\
\hline
\end{tabular}
shown in Table 1.

Table 1. Record of the data needed for the empirical study.

Source: Processing performed by the authors. ACI: Audit Committee Index; ROA: Return on Assets. 
Returning to the multiple regression model mentioned above as universal, at this point we can define it with the analyzed specific variables. As they have been presented, this results in a set of variables including dependent or independent variables. In order to add some value and certitude, we also used control variables.

After defining the variables we used in our model, we came to the following regression model:

$$
\text { Tobin's } Q=\beta_{0}+\beta_{1} \text { ACI }+\beta_{2} \text { Growth }+\beta_{3} \text { LnAssets }+\beta_{4} \text { ROA }+\alpha \text { it. }
$$

\subsection{Analysis of the Obtained Results and Their Implications}

By introducing the above defined data for the 47 entities, we obtained the following statistical results (Table 2).

Table 2. Statistical results.

\begin{tabular}{ccccccc}
\hline & & Tobin's Q & ACI & LnAssets & Growth & ROA \\
\hline \multirow{2}{*}{$\mathrm{N}$} & Valid & 53 & 53 & 53 & 53 & 53 \\
& Mean & 1.4565 & 52.39 & 20.7121 & 1.0442 & 0.2551 \\
Standard Deviation & 0.99763 & 2.54976 & 2.17658 & 0.0261 & 0.1095 \\
Variance & 0.455 & 457.635 & 4.4312 & 0.0712 & 0.012 \\
& Range & 2.14 & 100.00 & 9.65 & 5.45 & 1.72 \\
Minimum & 0.34 & 25 & 15.56 & 0.36 & -0.47 \\
Maximum & 2.50 & 100 & 28.18 & 2.42 & 32 \\
\hline
\end{tabular}

Source: Processing performed by the authors.

As can be seen in the above table, the average value of Tobin's $Q$ variable is 1.45 , which indicates that the replacement cost or the trade-in value (cash surrender value) is higher than the current market value. We can also observe a value of 52.39 for the index of corporate governance. The value of 52.39 is appropriate because, as has been proved in the previous study, in most of the entities the independence of the audit committee members is not totally respected. LnAssets has an average value of 20.71, and it represents the size of the entity, which can have a direct influence on the entity's value. The average value of the turnover growth reaches a percentage of 1.45 , which proves that the entities have experienced a fast development in recent years.

The profitability indicator has an average value of 0.25 . In order to verify the formulated hypotheses, we used the OLS model (least-squares regression). A value of the coefficient $R$ close to 0 indicates a minor regression. We consider that a regression is minor when the forecasted regression values are no better than those obtained by random guessing. If the null hypothesis is not rejected, the observed data do not allow the identification of a valid linear model; thus, the regression is not appropriate for the initially established forecasting aim.

\section{Testing Hypothesis and Results Interpretation}

A first step in our analysis was to verify the simultaneous influence of independent variables on the dependent variable, the logarithmic Tobin's coefficient. Tables 3 and 4 show the results obtained from our analysis.

Table 3. Variables Entered (Entered/Removed) ${ }^{b}$.

\begin{tabular}{cccc}
\hline Model & Variables Entered & Variables Removed & Method \\
\hline 1 & LnAssets, Growth, ACI, ROA ${ }^{\text {a }}$ & Enter \\
\hline & a . All requested variables entered; & \\
b. Dependent Variable: Tobin's (ln) & \\
\hline & Source: Processing performed by the authors.
\end{tabular}


Table 4. Representativeness of the correlations.

\begin{tabular}{ccccc}
\hline Model & $\boldsymbol{R}$ & $\boldsymbol{R}$ Square & $\begin{array}{c}\text { Adjusted } \boldsymbol{R} \\
\text { Square }\end{array}$ & $\begin{array}{c}\text { Standard Error of } \\
\text { the Estimate }\end{array}$ \\
\hline 1 & $0.537^{\mathrm{a}}$ & 0.197 & 0.153 & 0.03401 \\
\hline \multicolumn{4}{c}{ a. Predictors: (Constant), LnAssets, Growth, ACI, ROA } \\
\hline \multicolumn{4}{c}{ Source: Processing performed by the authors. }
\end{tabular}

We can notice that the value of the $R$ Square coefficient is 0.153 , which suggests that $15.3 \%$ of the Tobin's coefficient variance explain the variables of the regression model. The value of $15.3 \%$ cannot be considered a high value, but the global F-test allows us to assess the null hypothesis. For our case, studying the F-test within the regression analysis performed by using SPSS through ANOVA, we obtain a value of 8.162 with a higher probability value $p<0.001$ (Tables 5 and 6).

Table 5. ANOVA ${ }^{b}$.

\begin{tabular}{|c|c|c|c|c|c|c|}
\hline & Model & $\begin{array}{l}\text { Sum of } \\
\text { Squares }\end{array}$ & Df & $\begin{array}{l}\text { Mean } \\
\text { Square }\end{array}$ & $\mathbf{F}$ & Significance \\
\hline \multirow{3}{*}{1} & Regression & 6.539 & 5 & 1.217 & 8.162 & $0.000^{\mathrm{a}}$ \\
\hline & Residual & 26.754 & 166 & 0.157 & & \\
\hline & Total & 31.414 & 170 & & & \\
\hline \multicolumn{7}{|c|}{$\begin{array}{l}\text { a. Predictors: (Constant), LnAssets, Growth, ACI, ROA } \\
\text { b. Dependent Variable: Tobin's (ln) }\end{array}$} \\
\hline
\end{tabular}

Source: Processing performed by the authors.

Table 6. Coefficients ${ }^{\text {a. }}$

\begin{tabular}{|c|c|c|c|c|c|c|}
\hline Model & $\begin{array}{l}\text { Unstandardized } \\
\text { Coefficients }\end{array}$ & & $\begin{array}{l}\text { Standardized } \\
\text { Coefficients }\end{array}$ & $t$ & Significance & $\begin{array}{c}\text { Variance } \\
\text { Inflation Factor }\end{array}$ \\
\hline & B & Standard Error & Beta & & & \\
\hline (Constant) & 0.7452 & 0.2583 & & 2.2617 & 0.0054 & \\
\hline $\mathrm{ACI}$ & 0.0063 & 0.0018 & 0.2853 & 3.1941 & 0.0009 & 1.1205 \\
\hline Growth & 0.3897 & 0.0909 & 0.1404 & 2.0754 & 0 & 0.8883 \\
\hline ROA & 0.693 & 0.2322 & 0.1458 & 2.196 & 0.0108 & 0.9027 \\
\hline LnAssets & -0.0702 & 0.144 & -0.2052 & -4.3326 & 0 & 1.2303 \\
\hline Beta & 0.1386 & 0.0684 & 0.1305 & 1.7883 & 0.342 & 1.0584 \\
\hline \multicolumn{7}{|c|}{ a. Dependent Variable: Tobin's (ln) } \\
\hline
\end{tabular}

Source: Processing performed by the authors.

\subsection{Verification of Hypothesis $H_{1}$}

In order to reflect the manner in which the Audit Committee Index determines the increase of the entity's market value, we analyzed the correlation between the two variables using Pearson's coefficient (Table 7).

The correlation between the two variables is reflected in the table above. Pearson's coefficient, used to determine the correlation between the two quantitative variables, reached a value of 0.765 . This value suggests that there is a direct correlation of high intensity, as Pearson's coefficient can range between -1 and 1 , for which the value -1 represents the absence of a correlation between the two variables, and the value 1 represents a total correlation. In the table of correlation coefficients, we find the linear function, which reflects the influence on the market value according to the Audit Committee Index. This linear function can be represented by using the following function: as a result of the analysis undertaken in order to test the hypothesis $\mathrm{H}_{1}$, we can conclude that ACI significantly influences the entity's market value, which allows us to accept this hypothesis. 
Table 7. Correlation between variables.

\begin{tabular}{cccc}
\hline & & Tobin's & ACI \\
\hline \multirow{3}{*}{ Tobin's } & Pearson Correlation & 1 & $0.765^{* *}$ \\
& Significance (2-tailed) & & 0.000 \\
& N & 53 & 53 \\
\hline \multirow{2}{*}{ ACI } & Pearson Correlation & $0.765^{* *}$ & 1 \\
& Significance (2-tailed) & 0.000 & 53 \\
\hline & N & 53 & \\
\hline
\end{tabular}

\subsection{Verification of Hypothesis $\mathrm{H}_{2}$}

To reflect the manner in which the average growth of turnover determines the increase of the entity's market value, we analyzed the correlation between the two variables by using Pearson's coefficient (Table 8).

Table 8. Correlation between variables.

\begin{tabular}{|c|c|c|c|}
\hline & & Tobin's & Growth \\
\hline \multirow{3}{*}{ Tobin's } & Pearson Correlation & 1 & $0.824^{* *}$ \\
\hline & Significance (2-tailed) & & 0.000 \\
\hline & $\mathrm{N}$ & 53 & 53 \\
\hline \multirow{3}{*}{ Growth } & Pearson Correlation & $0.824^{* *}$ & 1 \\
\hline & Significance (2-tailed) & 0.000 & \\
\hline & $\mathrm{N}$ & 53 & 53 \\
\hline & $* *$. Correlation is sign & le $0.01 \mathrm{lev}$ & \\
\hline
\end{tabular}

The correlation between the two variables is reflected in the table above. Pearson's coefficient, used to determine the correlation between the two quantitative variables, reached a value of 0.824 . This value suggests that there is a direct correlation between the two variables, as Pearson's coefficient can range between -1 and 1 , for which the value -1 represents the absence of a correlation between the two variables, and the value 1 represents a total correlation. As a result of the analysis undertaken in order to test the hypothesis $\mathrm{H}_{2}$, we can conclude that Growth (average growth of turnover) significantly influence the entities' market value, which allows us to accept this hypothesis.

\subsection{Verification of Hypothesis $\mathrm{H}_{3}$}

In order to reflect the manner in which an entity's size determines the increase of its market value, we analyzed the correlation between the two variables by using Pearson's coefficient (Table 9).

The correlation between the two variables is reflected in the table above. Pearson's coefficient, used to determine the correlation between the two quantitative variables, reached a value of -0.379 . This value suggests that there is no direct correlation between the two variables, as Pearson's coefficient can range between -1 and 1 , for which the value -1 represents the absence of a correlation between the two variables, and the value 1 represents a total correlation. The negative value of the correlation between the two variables is not unexpected, as large entities have fewer opportunities for expansion [74]. As a result of the analysis undertaken in order to test the hypothesis $\mathrm{H}_{3}$, we can conclude that LnAssets does not significantly influence the entities' market value, which allows us to reject this hypothesis. 
Table 9. Correlation between variables.

\begin{tabular}{cccc}
\hline & & Tobin's & LnAssets \\
\hline \multirow{3}{*}{ Tobin's } & Pearson Correlation & 1 & $-0.379^{*}$ \\
& Significance (2-tailed) & & 0.028 \\
& N & 53 & 53 \\
\hline \multirow{3}{*}{ LnAssets } & Pearson Correlation & $-0.379^{*}$ & 1 \\
& Significance (2-tailed) & 0.028 & 53 \\
\hline & N & 53 & \\
\hline & Sorrelation is significant at the 0.05 level (2-tailed). \\
\hline
\end{tabular}

\subsection{Verification of Hypothesis $\mathrm{H}_{4}$}

In order to reflect the manner in which the entity's profitability indicator determines the increase of its market value, we analyzed the correlation between the two variables by using Pearson's coefficient (Table 10).

Table 10. Correlation between variables.

\begin{tabular}{|c|c|c|c|}
\hline & & Tobin's & ROA \\
\hline \multirow{3}{*}{ Tobin's } & Pearson Correlation & 1 & $0.843^{* *}$ \\
\hline & Significance (2-tailed) & & 0.000 \\
\hline & $\mathrm{N}$ & 53 & 53 \\
\hline \multirow{3}{*}{ ROA } & Pearson Correlation & $0.843^{* *}$ & 1 \\
\hline & Significance (2-tailed) & 0.000 & \\
\hline & $\mathrm{N}$ & 53 & 53 \\
\hline & Correlation is significar & .01 level & \\
\hline
\end{tabular}

The correlation between the two variables is reflected in the table above. Pearson's coefficient, used to determine the correlation between the two quantitative variables, reached a value of 0.843 . This value suggests that there is a direct correlation between the two variables, as Pearson's coefficient can range between -1 and 1 , for which the value -1 represents the absence of a correlation between the two variables, and the value 1 represents a total correlation. As a result of the analysis undertaken in order to test hypothesis $\mathrm{H}_{4}$, we can conclude that ROA (effectiveness of asset usage) significantly influences the entities' market value, which allows us to accept this hypothesis.

\section{Conclusions}

In the context of corporate governance, stakeholder interests are implicitly converging towards increasing performance and market value [81-83]. As a result of that, performance appears at the center of the concerns of companies that have a leadership based on the principles of corporate governance [82-85]. Well-thought-out and articulated structures of performance can operate in an efficient manner, leading implicitly to an increase in profitability for the company. Increasing the performance of the entity will ensure a higher degree of insurance for the shareholder. We believe that corporate governance represents a real chance for growth, with many companies investing time and sufficient money in the economy to grow in this climate, which is equity-based, value-based governance, by implementing systems and processes that are primarily intended to increase the performance and market value of the entity.

This study explores the role of an audit committee and what influence it has on the corporate governance system of an entity in order to measure its effect on market value. Nevertheless, the lack of some corporate governance frames or the existence of some which are inadequate, or the way in which 
the norms and rules are transposed in the frame of the implemented systems and processes, should also be considered.

Moreover, the results add new evidence to that on the implementation of the corporate governance system or of the principles that could contribute to the estimation of the capacity of the entity to generate future cash flows or improve the supplied services, aspects that would ensure the continuity of the considered entities.

This study is complementary to previous studies $[28,44,57,71,86-88]$ that have shown the role that corporate governance has in the frame of this process and, implicitly, in the drafting of the accounting synthesis accounts, as well as the role that these have in the governing of an entity.

In essence, it is necessary to approach corporate governance valences in the area of the accounting reporting process and to consider its impact through drafted reports on the system of leadership and control. In this way, the mechanisms through which the analyzed systems and processes interfere, condition, and influence each other can be identified, as well as the ways through which these, and also the relationships between the different interested parties, can be improved.

To provide support for our findings, we studied the connection between the audit committees and an entity's market value, and the following conclusions can be drawn:

- The audit committee is a corporate governance mechanism that can alleviate the problem of allocating power within the Principal-Agent Theory.

- The contribution of audit committees in corporate governance is to assess both the quality of financial reports and their approval. Financial reporting focuses on individual and consolidated financial statements, including the verification of external auditors.

- Creating an audit committee can have beneficial effects, which can eventually lead to a consolidation of a company's corporate governance: (1) the audit committee can help increase the efficiency of the monitoring system; (2) they can help restore and maintain the public's trust (this can eventually lead to lower capital costs and increase market value); (3) the coordination function is another important contribution of the audit committee regarding corporate governance.

In the same line of thinking, it should be noted that good corporate governance also includes an effective audit committee, although we cannot say that the inclusion of an audit committee represents the key to success in business. The audit committee cannot compensate or replace the judgment and leadership of top managers. However, the present study highlights the importance of an effective audit committee in conjunction with a solid business model, which must be interpreted more as an opportunity than a burdensome obligation.

Hence, one lesson from this research is, thus, that the audit committee makes a valuable contribution to strengthening corporate governance. Another lesson is that the architecture of the leading and controlling systems carries the mark of the frames, theories, principles, models, and practices of corporate governance.

In addition, our regression analysis is limited to a certain corporate governance mechanism, and we believe that this model can be extrapolated to several corporate governance mechanisms, although this action is practically difficult as different mechanisms are in differently connected. The figures emphasize that an audit committee can be effective only in a broader process of corporate governance. Therefore, the results of the present study must be carefully interpreted. Secondly, the independent variable is not a continuous variable, as the audit committee is effective within the limits of the five variables taken into consideration. Even so, the current statistical analysis is probably significant, at least for reference.

Author Contributions: Conceptualization, I.O., M.T.F., and M.P.; methodology, M.T.F. and D.I.T.; validation, I.O., M.T.F., and A.-G.P.; formal analysis, A.-G.P., F.-R.B., and M.P.; writing—original draft preparation, F.-R.B. and D.I.T.; writing-review and editing, I.O. All authors have read and agreed to the published version of the manuscript.

Funding: This research received no external funding.

Conflicts of Interest: The authors declare no conflict of interest. 


\section{References}

1. Chen, Y.-S.; Yang, C.-C.; Yang, Y.-F. Higher Academic Qualifications, Professional Training and Operating Performance of Audit Firms. Sustainability 2020, 12, 1254. [CrossRef]

2. Grigorescu, A.; Maer-Matei, M.M.; Mocanu, C.; Zamfir, A.M. Key Drivers and Skills Needed for Innovative Companies Focused on Sustainability. Sustainability 2020, 12, 102. [CrossRef]

3. Grewatsch, S.; Kleindienst, I. When Does It Pay to be Good? Moderators and Mediators in the Corporate Sustainability-Corporate Financial Performance Relationship: A Critical Review. J. Bus. Ethics 2017, 145, 383-416. [CrossRef]

4. Bird, R.; Hall, A.; Momente, F.; Reggiani, F. What Corporate Responsibility Activities Are Valued by the Market? J. Bus. Ethics 2007, 76, 189-206. [CrossRef]

5. Zamfir, A.M.; Mocanu, C.; Grigorescu, A. Circular economy and decision models among European SMEs. Sustainability 2017, 9, 1507. [CrossRef]

6. Aquilani, B.; Silvestri, C.; Ioppolo, G.; Ruggieri, A. The challenging transition to bio-economies: Towards a new framework integrating corporate sustainability and value co-creation. J. Clean. Prod. 2018, 172, 4001-4009. [CrossRef]

7. Rivera, J.M.; Munoz, M.J.; Moneva, J.M. Revisiting the Relationship Between Corporate Stakeholder Commitment and Social and Financial Performance. Sustain. Dev. 2017, 25, 482-496. [CrossRef]

8. Shah, K.U.; Arjoon, S.; Rambocas, M. Aligning Corporate Social Responsibility with Green Economy Development Pathways in Developing Countries. Sustain. Dev. 2016, 24, 237-253. [CrossRef]

9. Hategan, C.-D.; Curea-Pitorac, R.-I. Testing the Correlations between Corporate Giving, Performance and Company Value. Sustainability 2017, 9, 1210. [CrossRef]

10. Liang, H.; Renneboog, L. Corporate Donations and Shareholder Value; Finance Working Paper; European Corporate Governance Institute (ECGI): Brussels, Belgium, 2016.

11. Verbeeten, F.H.M.; Gamerschlag, R.; Möller, K. Are CSR disclosures relevant for investors? Empirical evidence from Germany. Manag. Decis. 2016, 54, 1359-1382. [CrossRef]

12. Moldavska, A. Defining Organizational Context for Corporate Sustainability Assessment: Cross-Disciplinary Approach. Sustainability 2017, 9, 2365. [CrossRef]

13. De Souza Cunha, F.A.F.; Samanez, C.P. Performance Analysis of Sustainable Investments in the Brazilian Stock Market: A Study about the Corporate Sustainability Index (ISE). J. Bus. Ethics 2013, 117, 19-36. [CrossRef]

14. Stefan, I.O. The implications of financial performance on stock exchange indicators of listed companies: Empirical evidence for the Romanian capital market. Audit Financ. 2016, 14, 875-896.

15. Reverte, C. The impact of better corporate social responsibility disclosure on the cost of equity capital. Corp. Soc. Responsib. Environ. Manag. 2012, 19, 253-272. [CrossRef]

16. Pirtea, M.; Botoc, C.; Jurcut, C. Risk and return analysis: Evidence from emerging markets. Transform. Bus. Econ. 2014, 13, 637-647.

17. Omar, B.F.; Zallom, N.O. Corporate social responsibility and market value: Evidence from Jordan. J. Financ. Rep. Account. 2016, 14, 2-29. [CrossRef]

18. Dowell, G.; Hart, S.; Yeung, B. Do corporate global environmental standards create or destroy market value? Manag. Sci. 2000, 46, 1059-1074. [CrossRef]

19. Yu, M.; Zhao, R. Sustainability and firm valuation: An international investigation. Int. J. Account. Inf. Manag. 2015, 23, 289-307. [CrossRef]

20. Ponemon, L.A. The Objectivity of Accountants' Litigation Support Judgements. Account Rev. 1995, 70, 467-488.

21. Ashkanasy, N.M.; Windsor, C.A. Personal and Organisational Factors Affecting Auditor Independence: Empirical Evidence and Directions for Future Research. Res. Account. Ethics 1997, 3, 35-48.

22. Farcane, N.; Deliu, D.; Bureană, E. A Corporate Case Study: The Application of Rokeach's Value System to Corporate Social Responsibility (CSR). Sustainability 2019, 11, 6612. [CrossRef]

23. Gino, F. Understanding ordinary unethical behavior: Why people who value morality act immorally. Curr. Opin. Behav. Sci. 2015, 3, 107-111. [CrossRef]

24. Aobdia, D.; Lin, C.; Petacchi, R. Capital market consequences of audit partner quality. Account. Rev. 2015, 90, 2143-2176. [CrossRef] 
25. Truant, E.; Corazza, L.; Scagnelli, S.D. Sustainability and Risk Disclosure: An Exploratory Study on Sustainability Reports. Sustainability 2017, 9, 636. [CrossRef]

26. Shin, H.; Lee, S.; Chang, J. Outside monitors and firm value. Korean J. Financ. 2004, 17, 41-72.

27. Lourenço, I.C.; Branco, M.C.; Curto, J.D.; Eugénio, T. How Does the Market Value Corporate Sustainability Performance? J. Bus. Ethics 2012, 108, 417-428. [CrossRef]

28. Baleanu, T.E.; Chelcea, L.; Stancu, A. The Social Responsibility of the Top 100 Romanian Companies. An Analysis of Corporate Websites. Amfiteatru Econ. J. 2011, 13, 237-250.

29. Hou, F.; Liao, F.; Liu, J.; Xiong, H. Signing Auditors' Foreign Experience and Debt Financing Costs: Evidence for Sustainability of Chinese Listed Companies. Sustainability 2019, 11, 6615. [CrossRef]

30. Guiral, A.; Rodgers, W.; Ruiz, E.; Gonzalo-Angulo, J.A. Can expertise mitigate auditors' unintentional biases? J. Int. Account. Audit. Tax. 2015, 24, 105-117. [CrossRef]

31. Abbott, L.; Parker, S. Auditor selection and audit committee characteristics. Audit. J. Pract. Theory 2000, 19, 47-66. [CrossRef]

32. Vafeas, N. Board meeting and firm performance. J. Financ. Econ. 1999, 53, 113-142. [CrossRef]

33. Braiotta, L. The Audit Committee Handbook, 3rd ed.; Wiley: New York, NY, USA, 1999.

34. Abbott, L.J.; Parker, S.; Peters, G.F.; Rama, D.V. Corporate governance, audit quality, and the Sarbanes-Oxley Act: Evidence from internal audit outsourcing. Account. Rev. 2007, 82, 803-835. [CrossRef]

35. Bradbury, M.E.; Mak, T.; Tan, S.M. Board characteristics, audit committee characteristics and abnormal accruals. Pac. Account. Rev. 2006, 18, 47-68. [CrossRef]

36. DeZoort, F.T.; Hermanson, D.R.; Houston, R.W. Audit Committee Support for Auditors: The Effects of Materiality Justification and Accounting Precision. J. Account. Public Pol. 2003, 22, 175-199. [CrossRef]

37. Goodwin-Stewart, J.; Kent, P. Relation Between External Audit Fees, Audit Committee Characteristics and Internal Audit. Account. Financ. 2006, 46, 387-404. [CrossRef]

38. Carcello, J.; Neal, T. Audit committee characteristics and auditor dismissals following 'new' going-concern reports. Account. Rev. 2003, 78, 95-117. [CrossRef]

39. Anderson, U.; Christ, M.; Johnstone, K.; Rittenberg, L. A post-SOX examination of factors associated with the size of internal audit functions. Account. Horiz. 2012, 26, 167-191. [CrossRef]

40. Cooper, S.M.; Owen, D.L. Corporate social reporting and stakeholder accountability: The missing link. Account. Organ. Soc. 2007, 32, 649-667. [CrossRef]

41. Jiang, C.; Fu, Q.A. Win-Win Outcome Between Corporate Environmental Performance and Corporate Value: From the Perspective of Stakeholders. Sustainability 2019, 11, 921. [CrossRef]

42. Orlitzky, M.; Swanson, D.L. Assessing Stakeholder Satisfaction: Toward a Supplemental Measure of Corporate Social Performance as Reputation. Corp. Reput. Rev. 2012, 15, 119-137. [CrossRef]

43. Gramling, A.A.; Maletta, M.J.; Schneider, A.; Church, B.K. The role of the internal audit function in corporate governance: A synthesis of the extant internal auditing literature and directions for future research. J. Account. Lit. 2004, 23, 194-244.

44. Knechel, W.; Vanstraelen, A. The relationship between auditor tenure and audit quality implied by going concern opinions. Audit. J. Pract. Theory 2007, 26, 113-131. [CrossRef]

45. Bame-Aldred, C.W.; Brandon, D.M.; Messier, W.F., Jr.; Rittenberg, L.E.; Stefaniak, C.M. A summary of research on external auditor reliance on the internal audit function. Audit. J. Pract. Theory 2013, 32 (Suppl. 1), 251-286. [CrossRef]

46. Krishnamoorthy, G.; Maletta, M. The Role of Internal Audit in the Financial Statement Audit: The Contingent Effects of Board Independence and Audit Committee Effectiveness; Working Paper; Northeastern University: Boston, MA, USA, 2012; pp. 1-29.

47. Zakaria, A. The Influence of the Audit Committee and the Remuneration Committee on Company Performance, KnE Social Sciences. In Proceedings of the International Conference on Islamic Finance, Economics and Business (ICIFEB), Tangerang, Indonesia, 11-12 October 2017; pp. 18-32.

48. Bajra, U.; Cadež, S. Audit committees and financial reporting quality: The 8th EU company law directive perspective. Econ. Syst. 2018, 42, 151-163. [CrossRef]

49. Ahmed, A.; Iwasaki, T. Foreign Ownership, Manager Monitoring, and Firm Value: Evidence from Japanese Firms; Working Paper; Texas A \& M University: College Station, TX, USA, 2015.

50. Spira, L. Audit Committees: Begging the Question? Corp. Gov. 2003, 11, 180-188. [CrossRef] 
51. Schreck, P. Reviewing the business case for corporate social responsibility: New evidence and analysis. J. Bus. Ethics 2011, 103, 167-188. [CrossRef]

52. Hay, D.; Knechel, W.; Ling, H. Evidence on the impact of internal control and corporate governance on audit fees. Int. J. Audit. 2008, 12, 9-24. [CrossRef]

53. Edmans, A. Blockholders and corporate governance. Annu. Rev. Financ. Econ. 2014, 6, 23-50. [CrossRef]

54. Bertschinger, P.; Schaad, M. Der amerikanische Sabanes -Oxley Act of 2002-Mögliche Auswirkungen auf die amerikanische und international Wirtschaftsprüfung und Corporate Governance. Der Schweiz. Treuhänd. 2003, 10, 883-888.

55. Pineiro-Chousa, J.; Romero-Castro, N.; Vizcaíno-González, M. Inclusions in and Exclusions from the S\&P 500 Environmental and Socially Responsible Index: A Fuzzy-Set Qualitative Comparative Analysis. Sustainability 2019, 11, 1211.

56. Čular, M.; Slapničar, S.; Vuko, T. The Effect of Internal Auditors' Engagement in Risk Management Consulting on External Auditors' Reliance Decision. Eur. Account. Rev. 2020. [CrossRef]

57. Yang, Y.; Stohl, C. The (in)congruence of measures of corporate social responsibility performance and stakeholder measures of corporate social responsibility reputation. Corp. Soc. Responsib. Environ. Manag. 2020, 27, 969-981. [CrossRef]

58. Collier, P.; Zaman, M. Convergence in European corporate governance: The audit committee concept. Corp. Gov. 2005, 13, 753-768. [CrossRef]

59. Klein, A. Audit committee, board of director characteristics, and earnings management. J. Account. Econ. 2002, 33, 375-400. [CrossRef]

60. Bryan, D.; Liu, M.H.; Tiras, S.L. The Influence of Independent and Effective Audit Committees on Earnings Quality. 2004. Available online: https://mpra.ub.uni-muenchen.de/42175/ (accessed on 28 October 2019).

61. Beasley, M.S.; Carcello, J.V.; Hermanson, D.R.; Lapides, P.D. Fraudulent Financial Reporting: Consideration of Industry Traits and Corporate Governance Mechanisms. Account. Horiz. 2000, 4, 441-454. [CrossRef]

62. Griffin, P.; Lont, D.; Sun, Y. Agency problems and audit fees: Further tests of the free cash flow hypothesis. Account. Financ. 2010, 50, 321-350. [CrossRef]

63. Eccles, R.G.; Krzus, M.P.; Watson, L.A. Integrated Reporting Requires Integrated Assurance. In Effective Auditing for Corporates: Key Developments in Practice and Procedures; Oringel, J., Ed.; Bloomsbury Information Ltd.: London, UK, 2012; pp. 161-178.

64. Keasey, K.; Wright, M. Issues in Corporate Accountability and Governance: An Editorial. Account. Bus. Res. 1993, 23, 291-303. [CrossRef]

65. Chtourou, S.M.; Bedard, J.; Courteau, L. Corporate Governance and Earnings Management; Working Paper; Laval University: Quebec City, QC, Canada, 2001; Available online: http://www.worldlii.org/int/journals/lsn/ abstracts/275053.html.

66. Pucheta-Martínez, M.C.; Fuentes, C. The impact of audit committee characteristics on the enhancement of the quality of financial reporting: An empirical study in the Spanish context. Corp. Gov. 2007, 15, 1394-1412. [CrossRef]

67. Vlaminck, N.; Sarens, G. The relationship between audit committee characteristics and financial statement quality: Evidence from Belgium. J. Manag. Gov. 2015, 19, 145-166. [CrossRef]

68. Ika, S.R.; Ghazali, N.A.M. Audit committee effectiveness and timeliness of reporting: Indonesian evidence. Manag. Audit. J. 2012, 27, 403-424.

69. Xie, B.; Davidson, W.; DaDalt, P. Earnings management and corporate governance: The roles of the board and the audit committee. J. Corp. Financ. 2003, 9, 295-316. [CrossRef]

70. Yang, J.S.; Krishnan, J. Audit Committees and Quarterly Earnings Management. Int. J. Audit. 2005, 9, $201-209$. [CrossRef]

71. Lee, K.-J. The effects of social responsibility on company value: A real options perspective of Taiwan companies. Econ. Res. Ekon. Istraž. 2019, 32, 3835-3852. [CrossRef]

72. Quazi, A.; Richardson, A. Sources of variation in linking corporate social responsibility and financial performance. Soc. Responsib. J. 2012, 8, 242-256. [CrossRef]

73. Abernathy, J.L.; Herrmann, D.; Kang, T.; Krishnan, G.V. Audit committee financial expertise and properties of analyst earnings forecasts. Adv. Account. 2013, 29, 1-11. [CrossRef] 
74. Choi, K.S.; Cho, W.H.; Lee, S.H.; Lee, H.J.; Kim, C.K. The Relationships among Quality, Value, Satisfaction and Behavioral Intention in Health Care Provider Choice: A South Korean Study. J. Bus. Res. 2004, 57, 913-921. [CrossRef]

75. Vuko, T.; Maretić, M.; Čular, M. The role and effectiveness of audit committee in corporate governance of credit institutions. Int. Sch. Sci. Res. Innov. 2015, 9, 1073-1077. [CrossRef]

76. Black, B.S.; Love, I.; Rachinsky, A. Corporate Governance and Firm's Market Values: Time Series Evidence from Russia. Emerg. Mark. Rev. 2006, 7, 361-379. [CrossRef]

77. Baker, M.; Wurgler, J. Market timing and capital structure. J. Financ. 2002, 57, 1-32. [CrossRef]

78. Beiner, S.; Schmid, M.M.; Drobetz, W.; Zimmermann, H. An Integrated Framework of Corporate Governance and Firm Valuation. Eur. Financ. Manag. 2006, 12, 249-283. [CrossRef]

79. Osazuwa, N.; Che-Ahmad, A. The moderating effect of profitability and leverage on the relationship between eco-efficiency and firm value in publicly traded Malaysian firms. Soc. Responsib. J. 2016, 12, $295-306$. [CrossRef]

80. Wiengarten, F.; Lo, C.K.Y.; Lam, J.Y.K. How does Sustainability Leadership Affect Firm Performance? The Choices Associated with Appointing a Chief Officer of Corporate Social Responsibility. J. Bus. Ethics 2017, 140, 477-493. [CrossRef]

81. Herdjiono, I.; Sari, I.M. The Effect of Corporate Governance on the Performance of a Company. Some Empirical Findings from Indonesia. J. Manag. Bus. Adm. 2017, 25, 33-52. [CrossRef]

82. Conway, E. To Agree or Disagree? An Analysis of CSR Ratings Firms. Soc. Environ. Accountab. J. 2019, 39, 152-177. [CrossRef]

83. Edwards, J.S.; Eggert, W.; Weichenrieder, A.J. Corporate Governance and Pay for Performance: Evidence from Germany. Econ. Gov. 2008, 10, 1-26. [CrossRef]

84. Defond, M.L.; Hann, R.N.; Hu, X. Does the market value financial expertise on audit committees of boards of directors? J. Account. Res. 2005, 43, 153-193. [CrossRef]

85. Galant, A.; Cadez, S. Corporate social responsibility and financial performance relationship: A review of measurement approaches. Econ. Res. Ekon. Istraž. 2017, 30, 676-693. [CrossRef]

86. Aldamen, H.; Duncan, K.; Kelly, S.; McNamara, R.; Nagel, S. Audit committee characteristics and firm performance during the global financial crisis. Account. Financ. 2012, 52, 971-1000. [CrossRef]

87. Bédard, J.; Chtourou, S.M.; Courteau, L. The effect of audit committee expertise, independence, and activity on aggressive earnings management. Audit. J. Pract. Theory 2004, 23, 13-35. [CrossRef]

88. Bolton, B. Audit Committee Performance: Ownership vs. Independence-Did SOX get it wrong? Account. Financ. 2014, 54, 83-112. [CrossRef]

(C) 2020 by the authors. Licensee MDPI, Basel, Switzerland. This article is an open access article distributed under the terms and conditions of the Creative Commons Attribution (CC BY) license (http://creativecommons.org/licenses/by/4.0/). 